\title{
Exploitation of algal-bacterial associations in a two-stage biohydrogen and biogas generation process
}

Roland Wirth ${ }^{1 \dagger}$, Gergely Lakatos ${ }^{2 \dagger}$, Gergely Maróti ${ }^{2}$, Zoltán Bagi ${ }^{1}$, János Minárovics ${ }^{4}$, Katalin Nagy ${ }^{4}$, Éva Kondorosi ${ }^{2}$, Gábor Rákhely ${ }^{1,3}$ and Kornél L Kovács ${ }^{1,3,4^{*}}$

\begin{abstract}
Background: The growing concern regarding the use of agricultural land for the production of biomass for food/feed or energy is dictating the search for alternative biomass sources. Photosynthetic microorganisms grown on marginal or deserted land present a promising alternative to the cultivation of energy plants and thereby may dampen the 'food or fuel' dispute. Microalgae offer diverse utilization routes.

Results: A two-stage energetic utilization, using a natural mixed population of algae (Chlamydomonas sp. and Scenedesmus sp.) and mutualistic bacteria (primarily Rhizobium sp.), was tested for coupled biohydrogen and biogas production. The microalgal-bacterial biomass generated hydrogen without sulfur deprivation. Algal hydrogen production in the mixed population started earlier but lasted for a shorter period relative to the benchmark approach. The residual biomass after hydrogen production was used for biogas generation and was compared with the biogas production from maize silage. The gas evolved from the microbial biomass was enriched in methane, but the specific gas production was lower than that of maize silage. Sustainable biogas production from the microbial biomass proceeded without noticeable difficulties in continuously stirred fed-batch laboratory-size reactors for an extended period of time. Co-fermentation of the microbial biomass and maize silage improved the biogas production: The metagenomic results indicated that pronounced changes took place in the domain Bacteria, primarily due to the introduction of a considerable bacterial biomass into the system with the substrate; this effect was partially compensated in the case of co-fermentation. The bacteria living in syntrophy with the algae apparently persisted in the anaerobic reactor and predominated in the bacterial population. The Archaea community remained virtually unaffected by the changes in the substrate biomass composition.
\end{abstract}

Conclusion: Through elimination of cost- and labor-demanding sulfur deprivation, sustainable biohydrogen production can be carried out by using microalgae and their mutualistic bacterial partners. The beneficial effect of the mutualistic mixed bacteria in $\mathrm{O}_{2}$ quenching is that the spent algal-bacterial biomass can be further exploited for biogas production. Anaerobic fermentation of the microbial biomass depends on the composition of the biogas-producing microbial community. Co-fermentation of the mixed microbial biomass with maize silage improved the biogas productivity.

Keywords: Microalgae, Biogas, Biohydrogen, Algal bacterial co-culture, Metagenomics

\footnotetext{
* Correspondence: kovacs.kornel@brc.mta.hu

${ }^{\dagger}$ Equal contributors

'Department of Biotechnology, University of Szeged, Közép fasor 52, H-6726

Szeged, Hungary

${ }^{3}$ Institute of Biophysics, Biological Research Center, Hungarian Academy of

Sciences, Temesvári krt. 62, H-6726 Szeged, Hungary

Full list of author information is available at the end of the article
}

\section{Biomed Central}

(c) 2015 Wirth et al.; licensee BioMed Central. This is an Open Access article distributed under the terms of the Creative Commons Attribution License (http://creativecommons.org/licenses/by/4.0), which permits unrestricted use, distribution, and reproduction in any medium, provided the original work is properly credited. The Creative Commons Public Domain Dedication waiver (http://creativecommons.org/publicdomain/zero/1.0/) applies to the data made available in this article, unless otherwise stated. 


\section{Introduction}

Biomass utilization for energy generation is commonly regarded as a major contributor to the achievement of renewable energy production targets [1-4]. Energy carriers from biomass are currently predominantly produced through the use of terrestrial plants [5]. The intensive exploitation of land for the cultivation of crops destined for biofuel production, however, may exert a negative impact on the global supply and the price of food and feed [6].

The search for alternative biomass sources still continues. Economically and environmentally friendly solutions should be found. Huge energetic and biorefinery opportunities are offered by the conversion of solar energy via the use of photosynthetic microorganisms. Hence, the interest in photosynthetic microorganisms (and especially microalgae) is growing worldwide. The microalgae are a large and diverse group of microscopic, photoautotrophic, or photoheterotrophic organisms, which grow profusely in both salt and fresh natural waters [7]. Microalgae are able to double their biomass much faster than terrestrial plants, and they therefore produce more biomass per hectare than higher plants do [8]. The relatively small land area needed to cultivate microalgae may be arable or marginal land, which further decreases the competition for agricultural land and smothers the 'food or fuel' dispute [7]. Microalgae can be harvested practically all year round, hence improving the biomass production efficacy and eliminating numerous storage problems. Cultivation is possible in closed photobioreactors or in open ponds. Open systems are usually considered to be economical, while closed systems are more efficient from the aspect of biomass production and control of the cultivation parameters $[9,10]$; either concept may therefore be competitive in diverse applications [11]. Additional beneficial features of a microalgal biomass include versatility and the variety of utilization for energetic purposes such as biohydrogen $\left(\mathrm{bioH}_{2}\right)$, bioethanol, biodiesel, and biogas production [12-14], besides biorefinery applications [14-16].

The important properties of a microalgal biomass to be used in anaerobic digestion (AD) include high contents of lipids and/or carbohydrates and a lack of recalcitrant lignin [12]. The lipid and carbohydrate content amounts up to $50 \%$ of the biomass dry weight in some strains $[10,17]$. Research on the AD of algal biomass started more than 50 years ago [18]. Until recently, only a few studies followed up this line of research [19-24]. Levels of biogas productivity from various fresh and salt water algal strains have been compared under mesophilic conditions [25]. The biogas potential was found to depend strongly on the species and on the cell disruption method applied. The $\mathrm{CH}_{4}$ content of the gas evolved from the microalgae was $7 \%$ to $13 \%$ higher than that from maize silage [25]. A closed-loop system to convert the algal biomass to biogas and electricity has been tested [26]. The microbial communities thriving in anaerobic digesters fed with algal biomass have not been investigated extensively. The archaeal community formed during microalgal fermentation was recently analyzed by next-generation sequencing [27].

Some microalgae, such as the most extensively studied green microalga Chlamydomonas reinhardtii, have the noteworthy ability to produce $\mathrm{H}_{2}$ via a photosynthetic water-splitting reaction coupled with the dark hydrolysis of storage materials [28-30]. Sulfur deprivation becomes a standard method through which to switch the algal metabolism from photoautotrophy to dark heterotrophic $\mathrm{H}_{2}$ generation. The two-step process during which the cells undergo major metabolic and biochemical changes demands considerable energy input both by the process operators and by the algae.

Naturally formed, mixed algal-bacterial microbial communities have been observed to have beneficial effects on algal growth [31-34]. The mutualistic relationship involves supplying the algae with important growth factors, notably vitamin $\mathrm{B} 12$, by the bacterial partner in exchange for organic nutrients [35-39]. Little is known about $\mathrm{H}_{2}$ production by algal-bacterial systems [40]. A recent study proposed that by consuming the $\mathrm{O}_{2}$ generated photosynthetically by the algae, the bacteria maintain an anaerobic environment suitable for algal bioH $\mathrm{b}_{2}$ production [41]. This may eliminate the need for the sulfur-deprivation step [28-30].

In this study, we modeled a two-stage biorefinery process, that is, $\mathrm{H}_{2}$ production in the first stage by an algal-bacterial mixed biomass grown under nonsterile photoheterotrophic conditions, with biogas generation from the residual biomass in the second stage. The composition of the microalgal-bacterial mixture was monitored during the process by using next-generation DNA sequencing technology.

\section{Results and discussion}

\section{$\mathrm{H}_{2}$ production by the mixed algal-bacterial system}

$\mathrm{H}_{2}$ accumulated in the reactor headspace and concomitantly $\mathrm{O}_{2}$ disappeared in time when a mixture of Scenedesmus sp. and Chlamydomonas sp. was cultivated under nonsterile conditions together with their natural mutualistic bacterial partners $(\mathrm{AB}+\mathrm{S}$ culture), which consumed the $\mathrm{O}_{2}$ produced by the algae. The results were compared with the $\mathrm{H}_{2}$ evolution by a mixture of the pure cultures of the two microalgae supplemented with hydrogenase-deficient Escherichia coli cells $(\mathrm{AE}+\mathrm{S}$ culture) and by sulfur-deprived, bacterium-free algal cultures (A-S culture) (Figure 1). Striking differences were observed in terms of accumulated $\mathrm{H}_{2}$ yields and the commencement and duration of $\mathrm{H}_{2}$ evolution.

In the headspace of the growing algal-bacterial culture, the $\mathrm{O}_{2}$ level decreased from $21 \%$ to $4.5 \%$ in $12 \mathrm{~h}$ (Figure 1B). The low $\mathrm{O}_{2}$ level allowed $\mathrm{H}_{2}$ evolution by the algal biomass 

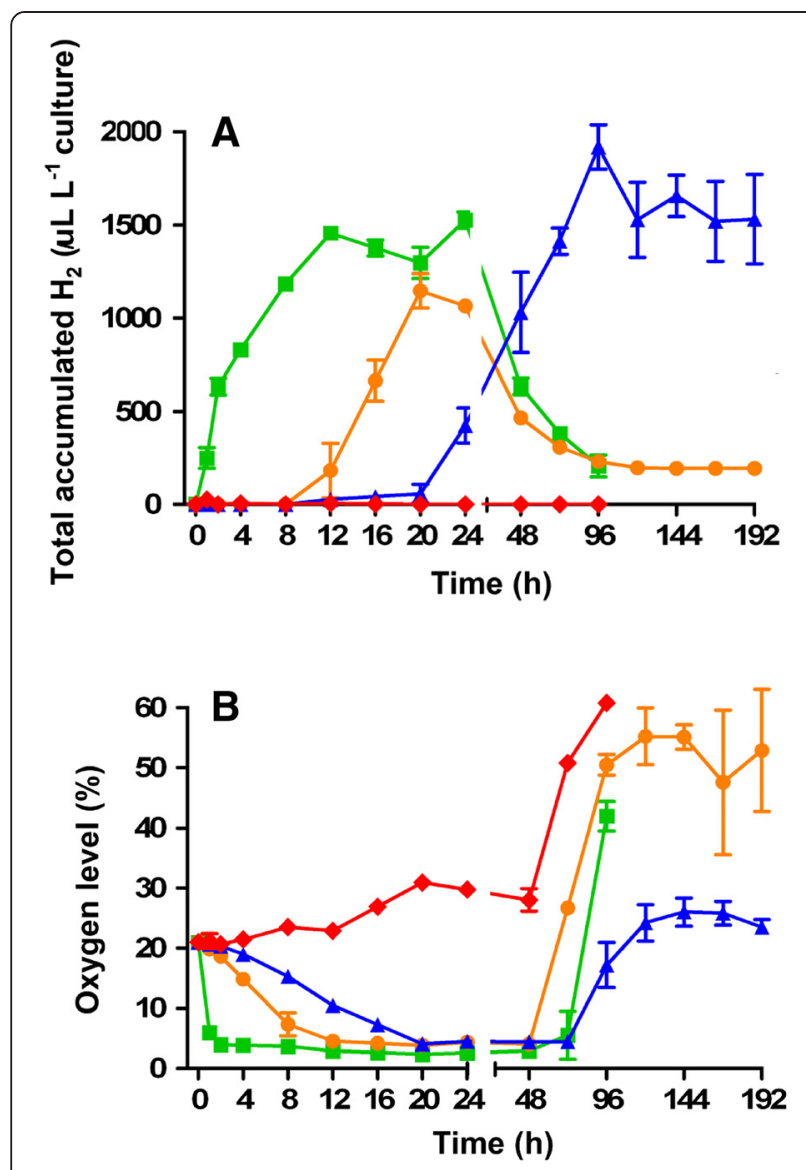

Figure $1 \mathrm{H}_{2}$ accumulation (A) and $\mathrm{O}_{2}$ content (B) in the

headspaces of the various cultures in time. Orange circles: mixed algal-bacterial co-culture $(A B+S)$; green squares: algal-bacterial mixture with added $E$. coli $\triangle \operatorname{hypF}(\mathrm{AE}+\mathrm{S})$; blue triangles: sulfur-deprived bacterium-free co-culture of Chlamydomonas sp. and Scenedesmus sp. (A-S); red diamonds: bacterium-free co-culture of Chlamydomonas sp. and Scenedesmus sp. without sulfur deprivation $(A+S)$.

after $8 \mathrm{~h}$ and $1.15 \pm 0.09 \mathrm{~mL} \mathrm{H}_{2} \mathrm{~L}^{-1}$ was produced during the next $16 \mathrm{~h}$, confirming earlier observations in similar systems (Figure 1A) [41].

The mutualistic bacteria were eliminated from the algal culture by photoautotrophic cultivation on minimal medium supplemented with rifampicin. $\mathrm{H}_{2}$ production was not observed of the bacterium-free algal culture (A $+\mathrm{S}$ ), because $\mathrm{O}_{2}$ was not consumed by the mutualistic bacteria and the biosynthesis of the $\mathrm{O}_{2}$ sensitive hydrogenases was repressed (Figure 1A,B). The facultative anaerobic wild-type $E$. coli tends to consume $\mathrm{O}_{2}$ when it is available. Under anaerobic conditions, $E$. coli evolves $\mathrm{H}_{2}$ by using its own hydrogenases [42]. In order to eliminate the contribution of $\mathrm{H}_{2}$ production by $E$. coli, a pleiotropic hydrogenase mutant $(\triangle h y p F)$ strain was used in these experiments so that only the facultative anaerobic property of this bacterium is functioning. Addition of $E$. coli $\triangle$ hypF cells and acetate to the pure algal culture $(\mathrm{AE}+\mathrm{S})$ efficiently reduced the level of $\mathrm{O}_{2}$ from $21 \%$ to $4 \%$ in $2 \mathrm{~h}$. Pronounced $\mathrm{H}_{2}$ production accompanied this condition $\left(1.52 \pm 0.04 \mathrm{~mL} \mathrm{H}_{2} \mathrm{~L}^{-1}\right)$ (Figure 1A). The bacterial cell number in the spontaneously formed algalbacterial culture $(A B+S)$ was markedly lower than in the algal-E. coli $\triangle h y p F$ co-culture $(\mathrm{AE}+\mathrm{S})$, which may explain why $\mathrm{H}_{2}$ generation by the $\mathrm{AE}+\mathrm{S}$ started earlier than without the $\mathrm{O}_{2}$ scavenger E. coli strain (Figure 1). These data were compared with the $\mathrm{H}_{2}$ production by the mixture of the pure algal strains using the photoheterotrophic TRIS-acetate-phosphate medium (TAP) and employing the sulfur-deprivation method $[43,44]$. The sulfur-deprived pure Scenedesmus sp. and Chlamydomonas sp. mixture (A-S culture) became anaerobic after 20 $\mathrm{h}$ as opposed to the 2 to $8 \mathrm{~h}$ in the case of $\mathrm{AB}+\mathrm{S}$ and $\mathrm{AE}+\mathrm{S} . \mathrm{H}_{2}$ evolution starts when anaerobic conditions are established; therefore, the difference in time required to reach anaerobicity is critical for the efficacy of the process. Additional benefits from practical aspect are the lower cost of alga production under nonsterile conditions and the elimination of labor- and cost-intensive transfer of algae into the sulfur-deficient medium.

The highest level of $\mathrm{H}_{2}$ generation by the A-S $(1.91 \pm 0.12$ $\mathrm{mL} \mathrm{H}_{2} \mathrm{~L}^{-1}$ ) was reached after 4 days (Figure $1 \mathrm{~A}$ ), which exceeded the $\mathrm{H}_{2}$ production of the $\mathrm{AE}+\mathrm{S}$ culture only by about $20 \%$. In view of the exceptionally thick cell walls of the Scenedesmus strains, the $\mathrm{H}_{2}$ productivity may have been partly diffusion-limited in the mixed algal culture, which may explain the lower $\mathrm{H}_{2}$ yield of A-S relative to the pure culture of sulfur-deprived Chlamydomonas sp. 549 strain $\left(2.63 \pm 0.04 \mathrm{~mL} \mathrm{H}_{2} \mathrm{~L}^{-1}\right)$ reported earlier [41]. Taken together, these experiments demonstrated that algal-bacterial natural mutualistic consortia are superior to the bacterium-free sulfur-deprived algal cultures from the aspect of $\mathrm{H}_{2}$ evolution.

There are two possible reasons why the $\mathrm{H}_{2}$ production ceased after about $24 \mathrm{~h}$ in the algal-bacterial cocultures cultivated in TAP medium (see the 'Materials and methods' section). First, the $\mathrm{H}_{2}$ yield depends on the $\mathrm{H}_{2}$ partial pressure in a closed system [45]. Removal of the product $\mathrm{H}_{2}$ from the headspace allows the extension of the production time, leading to sustainable $\mathrm{H}_{2}$ evolution (data not shown). Secondly, in separate experiments, we have demonstrated that the depletion of acetate also results in a rapid loss of the mutualistic bacteria [41]. This can be remedied by the systematic addition of acetic acid to the system. Acetate is a lowvalue commodity produced in a number of anaerobic fermentative processes. The limiting factors of this $\mathrm{bioH}_{2}$ production methodology appear to be relatively easy to overcome. $\mathrm{H}_{2}$ production by algae under nonsterile conditions may make this approach economically viable on a large scale. 
Biogas production from algal-bacterial mixed biomass

The levels of biogas production from the various biomass substrates were determined after a 1-month of start-up and stabilization phase, that is, in weeks 1 to 4 of the experiment. During this time, the reactors were fed with the $A B+S$ substrate to ensure that all the remaining and digestible biomass from the inoculum (containing pig slurry and maize silage) had been degraded and did not contribute to the biogas formation. Gas production data were collected during weeks 5 to 9 , when the evolved gas was produced from the $A B+S$ biomass. Biogas generation from the algal-bacterial mixture was compared with co-fermentaion of the alga-rich biomass and maize silage, and reactors fed with maize silage were used as controls. The $\mathrm{CH}_{4}$ concentration in the gas made from the $\mathrm{AB}+\mathrm{S}$ biomass substrate was $58 \%$ to $61 \%$, which is comparable to previous findings $[25,26,46]$. The biogas $\mathrm{CH}_{4}$ content from maize silage alone was $50 \%$ to $52 \%$, as found previously [47]. The cofermentation of algal-bacterial biomass with maize silage, in a ratio of $1: 1$, on the basis of organic dry matter (oDM), yielded a $\mathrm{CH}_{4}$ content of $54 \%$ to $57 \%$, an intermediate value between those for maize silage and the algal-bacterial biomass. The daily average generated biogas volumes were as follows: from maize silage $3.20 \mathrm{~L}$ day $^{-1}$, from co-fermentation $3.15 \mathrm{~L}_{\text {day }}{ }^{-1}$, and from algal-bacterial mixture $2.20 \mathrm{~L} \mathrm{day}^{-1}$. Figure 2 shows the specific average $\mathrm{CH}_{4}$ production values $(\mathrm{mL})$ calculated for $\mathrm{g} \mathrm{oDM}^{-1}$.

For the appreciation of the potential value of the $A B+S$ biomass as biogas substrate, its advantages relative to the widely used maize silage have to be taken into account. Most importantly, the $\mathrm{AB}+\mathrm{S}$ biomass can be cultivated under nonsterile conditions on lands not useful for agricultural production and can be continuously harvested during extended period of the year. Although several technical issues related to the large-scale production of $\mathrm{AB}+\mathrm{S}$ biomass for energetic purpose remain to be elaborated, this material may effectively replace a large portion of maize silage in the biogas reactors.

\section{VOAs/TAC ratio indicated stable operation}

The ratio of the volatile organic acids (VOAs) and the total alkaline capacity (TAC) is an appropriate measure of the functional stability of the anaerobic digestion process $[48,49]$. A VOAs/TAC ratio below 0.1 means that the reactor needs feeding, whereas at a ratio $\geq 0.5$ the biomass input is excessive and the process is out of balance. During the experiments, the average content of VOAs was $1.5 \mathrm{~g} \mathrm{~L}^{-1}$ and the average TAC was between 9 and $10 \mathrm{~g} \mathrm{CaCO}_{3} \mathrm{~L}^{-1}$ in all cases. Figure 3 shows the weekly measured VOAs/TAC ratios.

A constant value of VOAs/TAC is a reliable indicator of a stable fermentation process. The organic loading rate was on the low side and allowed stable and balanced operation.

\section{$\mathrm{NH}_{4}^{+}$accumulation}

From the decomposition of nitrogen-containing compounds, ammonia $\left(\mathrm{NH}_{3}\right)$ is formed, which is present in the aqueous medium in the form of ammonium ion $\left(\mathrm{NH}_{4}^{+}\right)$[50]. Values above 3,000 $\mathrm{mg} \mathrm{NH}_{4}^{+} \mathrm{L}^{-1}$ may have a negative effect on the methanogenic community [51,52]. During the anaerobic fermentation, slight fluctuations in the weekly $\mathrm{NH}_{4}^{+}$concentrations were observed. In the case of using the algal-bacterial mixture, the $\mathrm{NH}_{4}^{+}$content

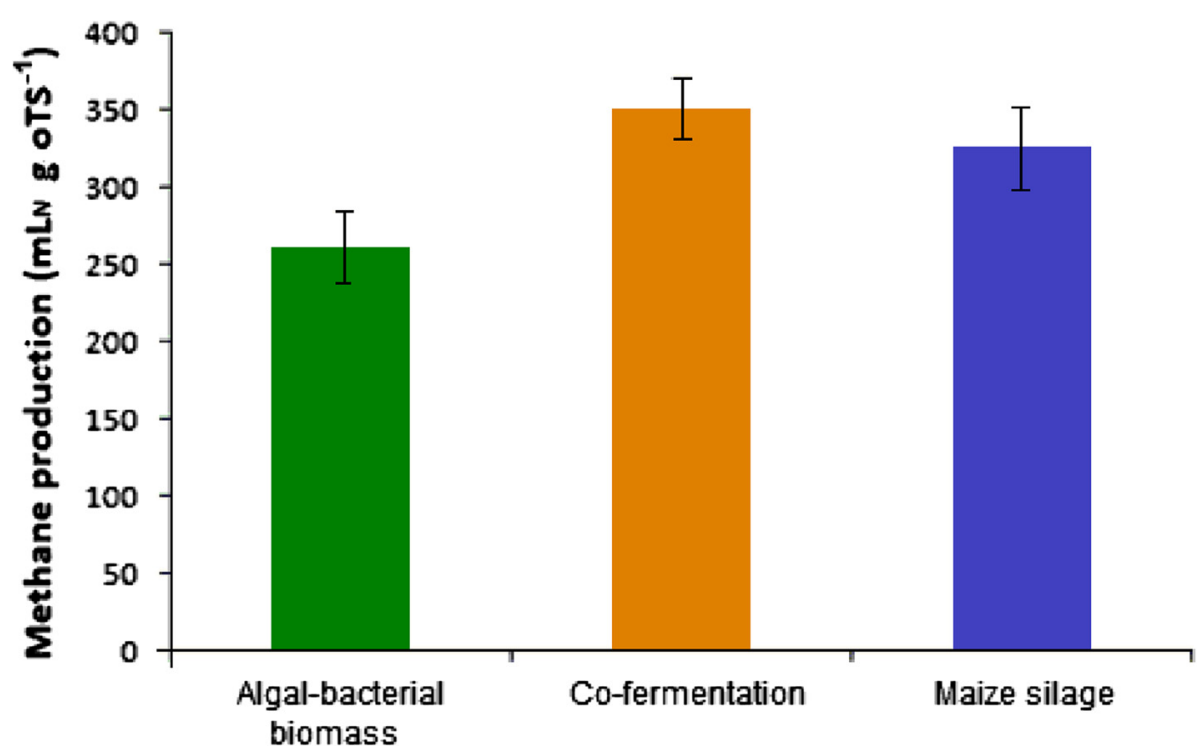

Figure 2 Specific $\mathrm{CH}_{4}$ production from the various biomasses. 


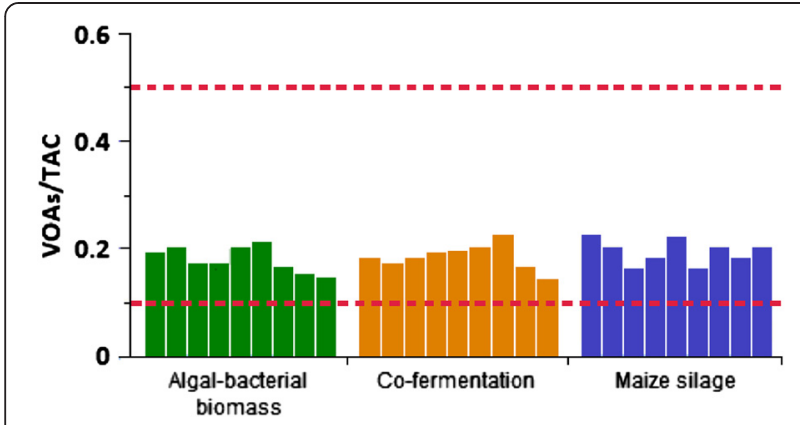

Figure 3 Weekly measured VOAs/TAC ratios. The area between the dashed red lines indicates the optimum range.

tended to increase but remained under the critical 3,000 $\mathrm{mg} \mathrm{NH}_{4}^{+} \mathrm{L}^{-1}$ level (Figure 4). Co-fermentation efficiently balanced this elevated $\mathrm{NH}_{4}^{+}$level.

\section{The effect of the $\mathrm{C} / \mathrm{N}$ ratio}

The ideal $\mathrm{C} / \mathrm{N}$ ratio for $\mathrm{AD}$ is 20 to 30 [53,54], because the microbes in the anaerobic reactor can utilize carbon (C) 20 to 30 times faster than nitrogen (N) [54]. The risk of $\mathrm{C}$ starvation increases if the $\mathrm{C} / \mathrm{N}$ ratio is lower than 20; the methanogens are inhibited by the high $\mathrm{NH}_{3}$ accumulation, making the $\mathrm{AD}$ process vulnerable. At the other end of the spectrum, if the $\mathrm{C} / \mathrm{N}$ ratio exceeds 30 , the concentration of volatile fatty acids escalates, leading to process inhibition. The $\mathrm{C} / \mathrm{N}$ ratios of the substrates used in this work are presented in Table 1. During the fed-batch continuous $\mathrm{AD}$ of microalgae and their mutualistic bacterial flora $(A B+S)$, the nitrogen content increased. The initial $\mathrm{C} / \mathrm{N}$ ratio of the $\mathrm{AB}+\mathrm{S}$ biomass was low, 5.3. The nitrogen content increased as the fermentation progressed (Figure 5), accompanied by a slight but persistent free $\mathrm{N}$ concentration increase. Co-fermentation of the algal-bacterial biomass with maize silage, which had a $\mathrm{C} / \mathrm{N}$ ratio of 45.3 , led to a less pronounced $\mathrm{N}$ accumulation, indicating a buffering effect of the maize silage. In the reactors fed with maize silage alone, the $\mathrm{N}$ level remained nearly constant (Figure 5).

Olsson et al. reported that feeding AD reactors with a high proportion of microalgal biomass in co-fermentation with waste water sludge had a negative effect under both thermophilic $\left(55^{\circ} \mathrm{C}\right)$ and mesophilic $\left(37^{\circ} \mathrm{C}\right)$ conditions, possibly because of the high $\mathrm{N}$ content of the microalgal biomass [55]. Co-fermentation of a microalgal biomass with waste paper improved the AD performance [56], presumably in consequence of the higher $\mathrm{C} / \mathrm{N}$ ratio of the mixed substrate and the induction of cellulase biosynthesis by the paper sludge. In our case, co-fermentation of the algal-bacterial biomass with the cellulose-rich maize silage likewise enhanced the biogas productivity.

\section{Microbial community}

The composition of the microbial community was established at four time points: at the start of feeding with the selected substrate (start), 1 week later (week 1), when the system was working at full capacity (week 5 ), and at the end of the process (week 9). The microbial community compositions of the substrates were determined separately.

\section{Microbiological compositions of the substrates}

The microbial flora of the maize silage included representatives of the genera Lactobacillus and Acetobacter, as expected (Figure 6A). Lactobacilli produce lactate from mono- and disaccharides [57]. Upon ensilaging, the accumulating acid decreases the $\mathrm{pH}$ and preserves the green plant material. Members of the genus Acetobacter primarily contribute to acetate production [58].

The mixture of Chlamydomonas sp. and Scenedesmus $s p$. microalgae was cultivated under nonsterile conditions and contained copious amounts of the mutualistic bacteria (Figure 6B). Rhizobium species predominated in the bacterial population. Rhizobium is well known for its syntrophic interaction with plants and mutualism has also been observed in the cases of several microalgal

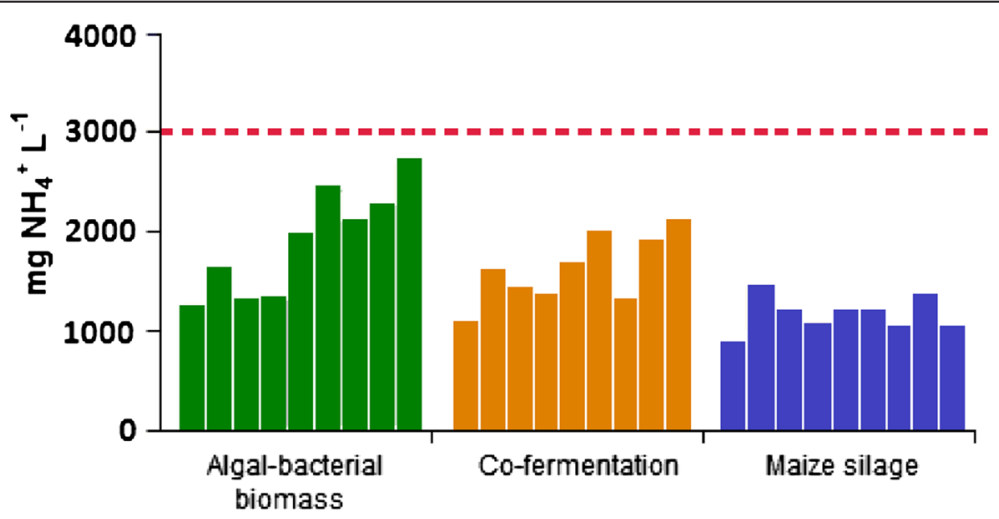

Figure 4 Weekly measured $\mathrm{NH}_{4}^{+}$concentrations. The dashed red line indicates the highest value recommended by the various studies. 
Table 1 The initial substrate compositions

\begin{tabular}{llllll}
\hline Substrate & Wet mass $\mathbf{N}\left(\mathbf{m g ~ g}^{-\mathbf{1}}\right)$ & Wet mass $\mathbf{C}\left(\mathbf{m g ~ g}^{-\mathbf{1}}\right)$ & C/N ratio & TS (\%) & oDM (\%) \\
\hline Maize silage & 4.35 & 196.86 & $45.3: 1$ & 41.19 & 94.59 \\
Algal-bacterial mix & 18.65 & 98.33 & $5.3: 1$ & 30.30 & 97.71 \\
\hline
\end{tabular}

TS = total solids, oDM = organic dry material.

species $[36,39]$. The major probable driving force behind this association is vitamin $B_{12}$, which the algae needs for growth but cannot synthesize. Rhizobium is there to supply the algae with vitamin $B_{12}$ in exchange for fixed carbon. The growth rate and the resistance to environmental stresses improve as a result of the algal-bacterial interactions [36,39]. Other forms of mutualism between microalgae and bacteria have also been recognized [31-34].

\section{The biogas-producing microbial community}

The distribution of the microbial taxa in the biogasproducing microbial community at the beginning of the experiments was very similar to that found in earlier studies on reactors fed with pig manure and maize silage [59], in good agreement with starting the reactors with inocula from a mesophilic industrial biogas facility digesting such substrates. These results may therefore be regarded as an internal control validating the metagenome sequencing method. In the following detailed analysis of the metagenomic results, the unidentified sequences are disregarded.

\section{Microbial community of maize silage $A D$ (domain Bacteria)}

Only relatively minor and trivial rearrangements occurred in the relative distribution of the bacterial taxa during the experimental period (Figure 7). This is not surprising in view of the fact that the reactors were sustained on pig manure and maize silage prior to the start of the experiment. In the domain Bacteria, the most abundant strains belong in the phylum Firmicutes. Pronounced changes were seen in the phylum Proteobacteria. Some of the Proteobacteria were apparently displaced by Firmicutes and Bacteroidetes. In the phylum Firmicutes, the orders Clostridiales and Bacteroidales predominated (Figure 8). Among the Clostridiales, the genus Clostridium increased in abundance, followed by the genus Bacillus. In the order Bacteroidales, the genus Bacteroides predominated (data not shown).

\section{Microbial community of co-fermentation (domain Bacteria)}

Co-fermentation of the algal-bacterial mixture with maize silage provoked major changes in the composition of the bacterial community within a week as compared with the $\mathrm{AD}$ of maize silage (Figures 7 and 8). At the starting time point, there was no difference between the reactors fed with the various substrate compositions, indicating that the same microbial community was established during the start-up phase and the initial conditions were therefore identical. Supplying the reactors with a 1:1 mixture of microbial biomass and maize silage instigated a rearrangement within the biogasproducing microbial community. Representatives of the phylum Proteobacteria gradually predominated in the community, and within the taxon, the orders Rhizobiales and Burkholderiales prevailed (Figure 8). At higher resolution, a marked accumulation of the genera Rhizobium and Burkholderia was evident as the experiment progressed, although the phylum Proteobacteria displayed a diverse representation at the start. At the same time, members of the phylum Firmicutes and to a lesser degree those belonging to the phylum Bacteroidetes lost their significance within the $\mathrm{AD}$ community. The majority of bacteria belonging in these taxa have gained a reputation as outstanding cellulose degraders and $\mathrm{H}_{2}$ producers, both of these metabolic activities being crucial for efficient biogas production from plant biomass.

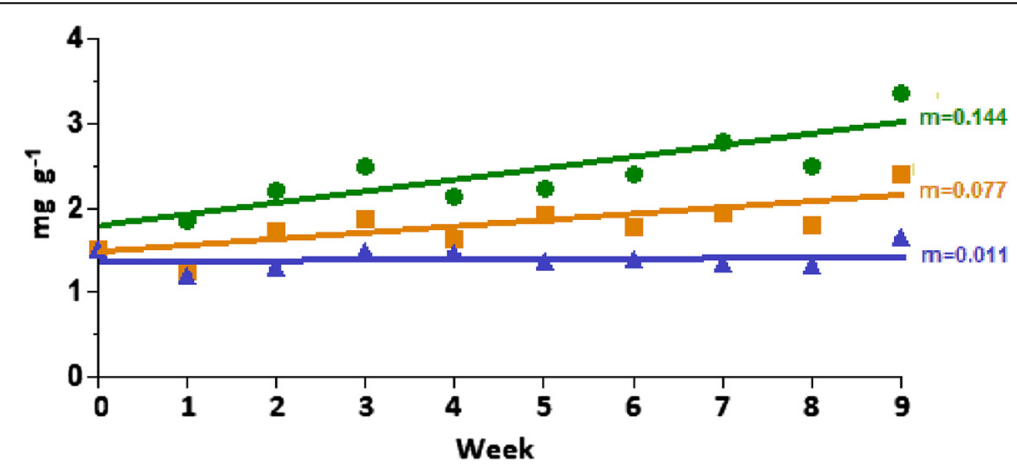

Figure 5 Changes in $\mathbf{N}$ content during the $\mathbf{A D}$ of various substrates. Green: $A B+S$, orange: co-fermentation, blue: maize silage. 


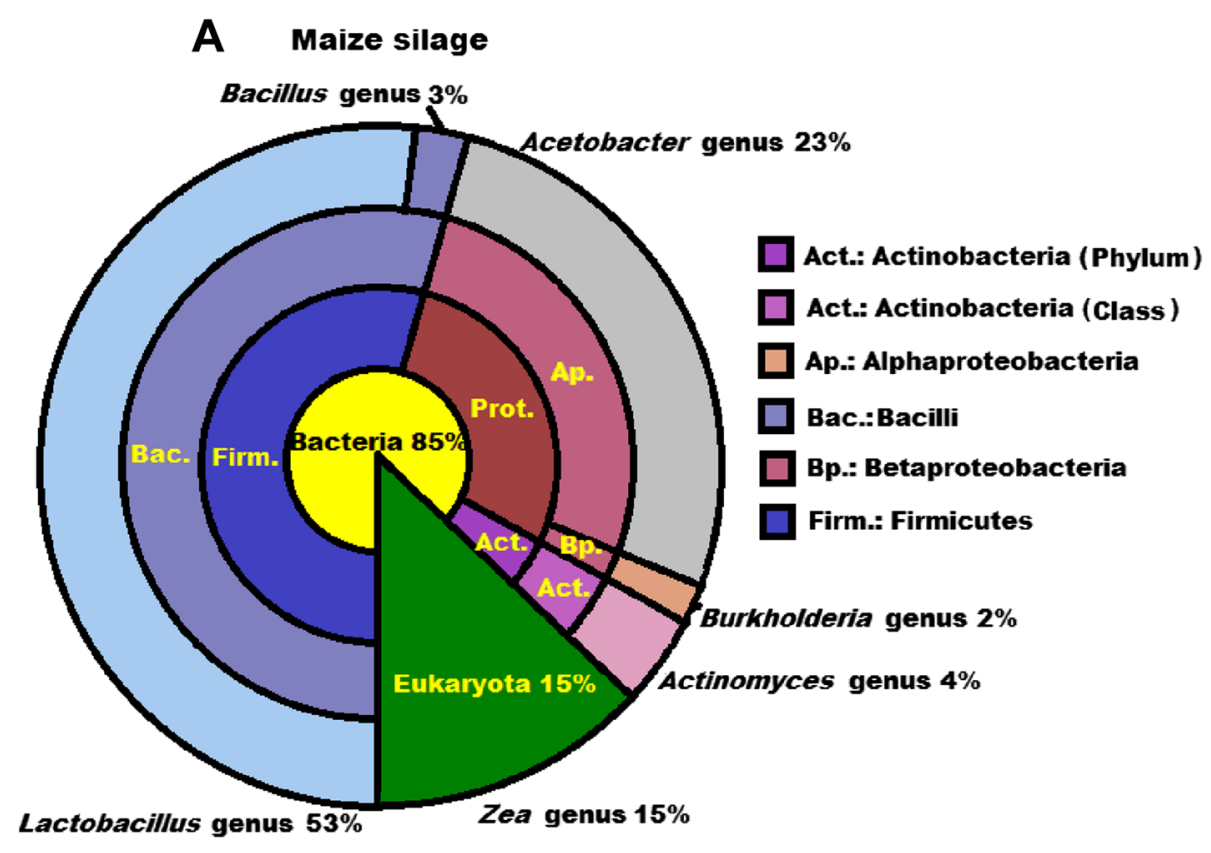

B Algal-bacterial biomass

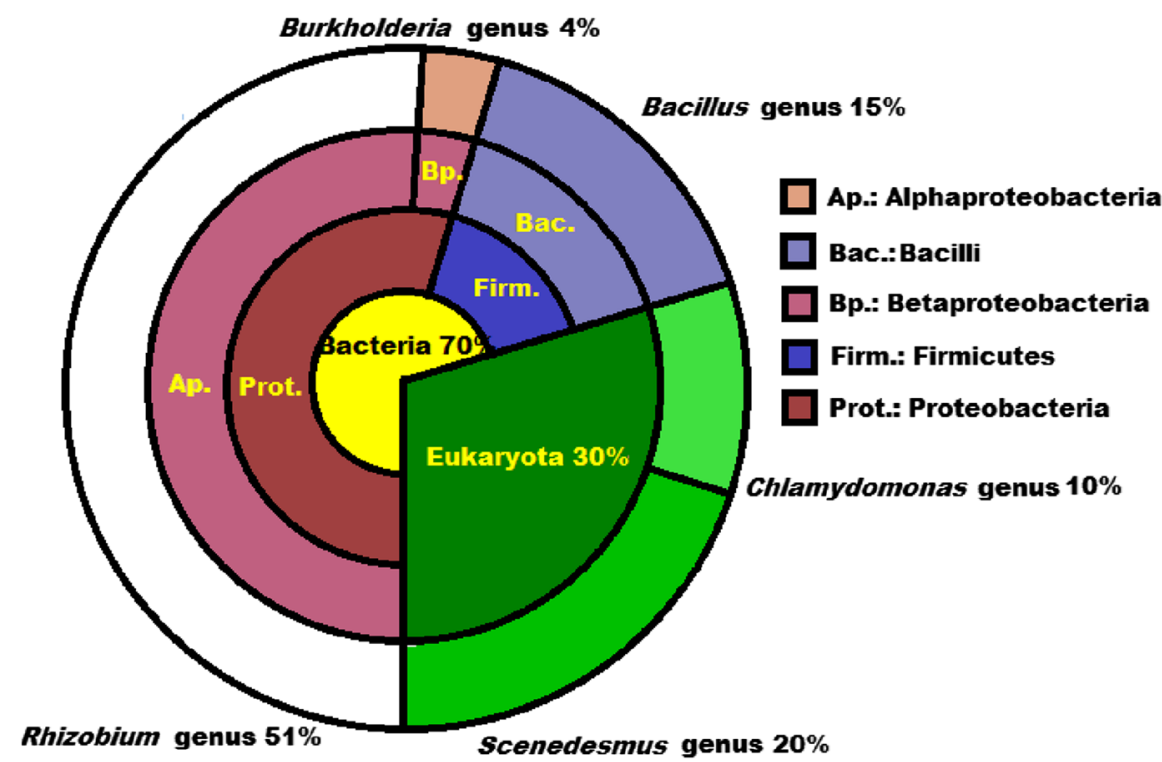

Figure 6 Microbial compositions of the substrates: (A) Maize silage, (B) AB + S. The communities at domain, phylum, class, and genus levels are indicated.

Microbial community of microalgal-bacterial fermentation (domain Bacteria)

A noteworthy fast response by the biogas-producing microbial community was observed when the substrate added to the reactors was changed from the mixture of pig slurry and maize silage to the algal-bacterial biomass. The reaction was less pronounced, but similar when the reactors were fed with a 1:1 mix of plant and microbial biomasses, as discussed above. The main outcome of this reorganization was the predominance of the phylum Proteobacteria, which surpassed the phyla Firmicutes and Bacteroidetes. The genera Rhizobium and Burkholderia were introduced into the reactor with the substrate (Figure 6) and accumulated in time (Figure 8), in spite of the relatively low daily organic loading rate. Either the decomposition was too slow to convert the total administered bacterial biomass to biogas, or the Rhizobia multiplied faster than their anaerobic degradation. Rhizobium species survive in free living form under anaerobic 


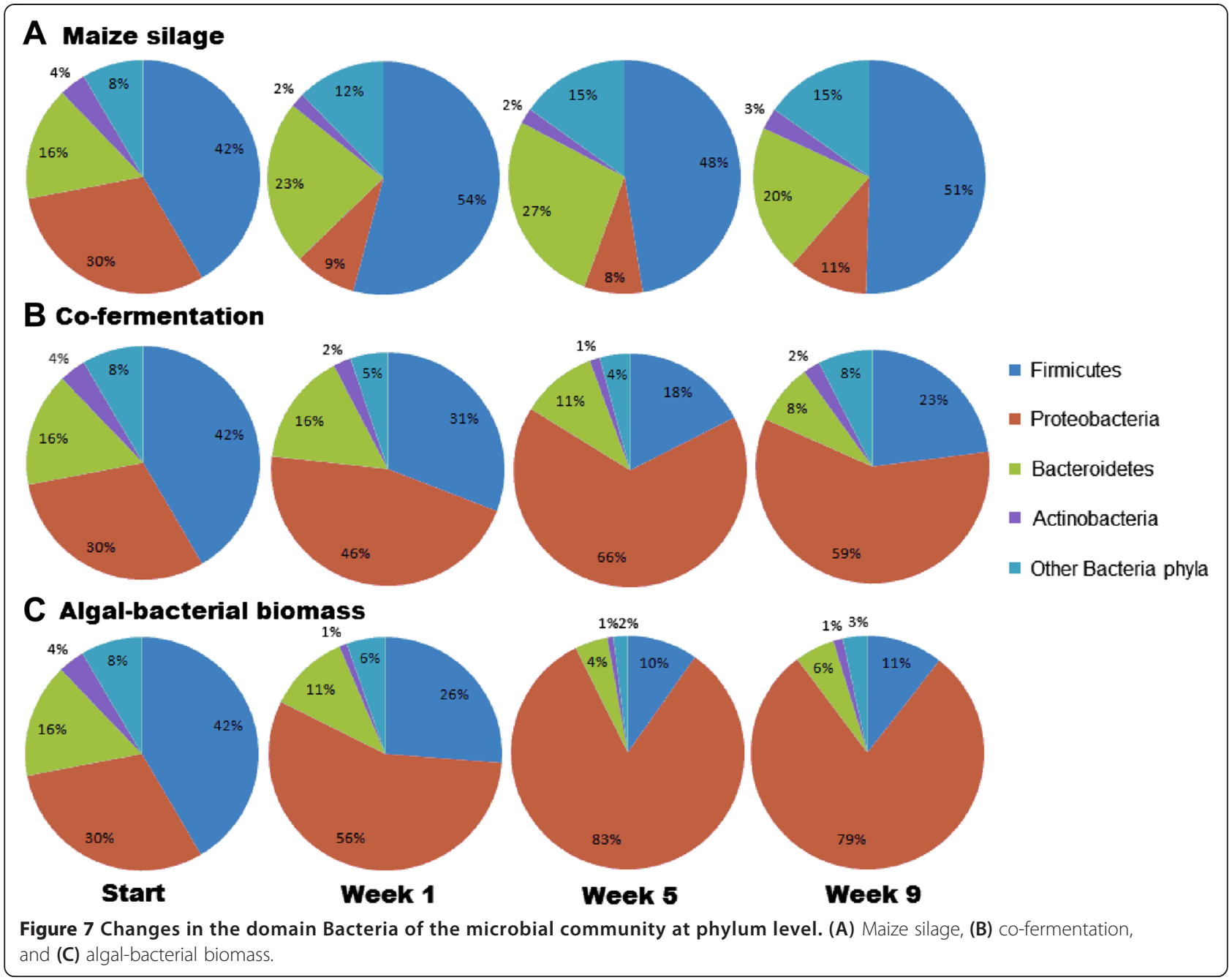

conditions, taking advantage of their nitrate respiration capability $[60,61]$, but it is unlikely that their growth rate exceeds that of the anaerobic degradation by the biogas microbial community. The substrate was stored at $-20^{\circ} \mathrm{C}$ for about 3 months before being fed into the reactors. It seems likely that the build-up of Proteobacteria in time is due to their relatively slow decomposition under the $\mathrm{AD}$ conditions. In this respect, it is noteworthy that the relative abundance of eukaryotic sequences in the reactors also increased in time (Figure 9). The eukaryotic DNA accumulation from the algal biomass was twice that from the maize, suggesting that the algal cell wall may be more resistant than that of the maize silage to microbial degradation.

This implies that the biogas potential of the algal biomass is higher than that of the bacterial biomass, although a correct mass balance is difficult to achieve because of the complexity of the organic materials in the reactor.

\section{The domain Archaea}

In the domain Archaea, a microbial composition was found that was distinct from those observed in previous studies in reactors fed with 'conventional' substrates [59,62-66]. The class Methanomicrobia represented the domain Archaea in great abundance. The Methanomicrobia are able to operate all three routes of methanogenesis [67]. The order Methanomicrobiales was the most prevalent from the start, and at higher resolution, the members of the genus Methanosarcina predominated. Seasonal changes or other uncontrolled factors may also be responsible for these alterations in the $\mathrm{AD}$ communities [68-70]. At any rate, the genus Methanosarcina remained predominant in all fermentations tested in this study (Figure 10). Interestingly, in a previous study, involving the use of next-generation sequencing $m c r A$ genes, the order Methanosarcinales was also found to be predominant in the $\mathrm{AD}$ of a mixture of waste water sludge and a nonsterile, unidentified algal biomass [27]. In the Archaeal community converting that substrate to biogas, the acetotrophic genus Methanosaeta (order Methanosarcinales) was identified as the prevailing taxonomic unit. Members of the genus Methanosaeta were present in our study too, although in less abundance. 

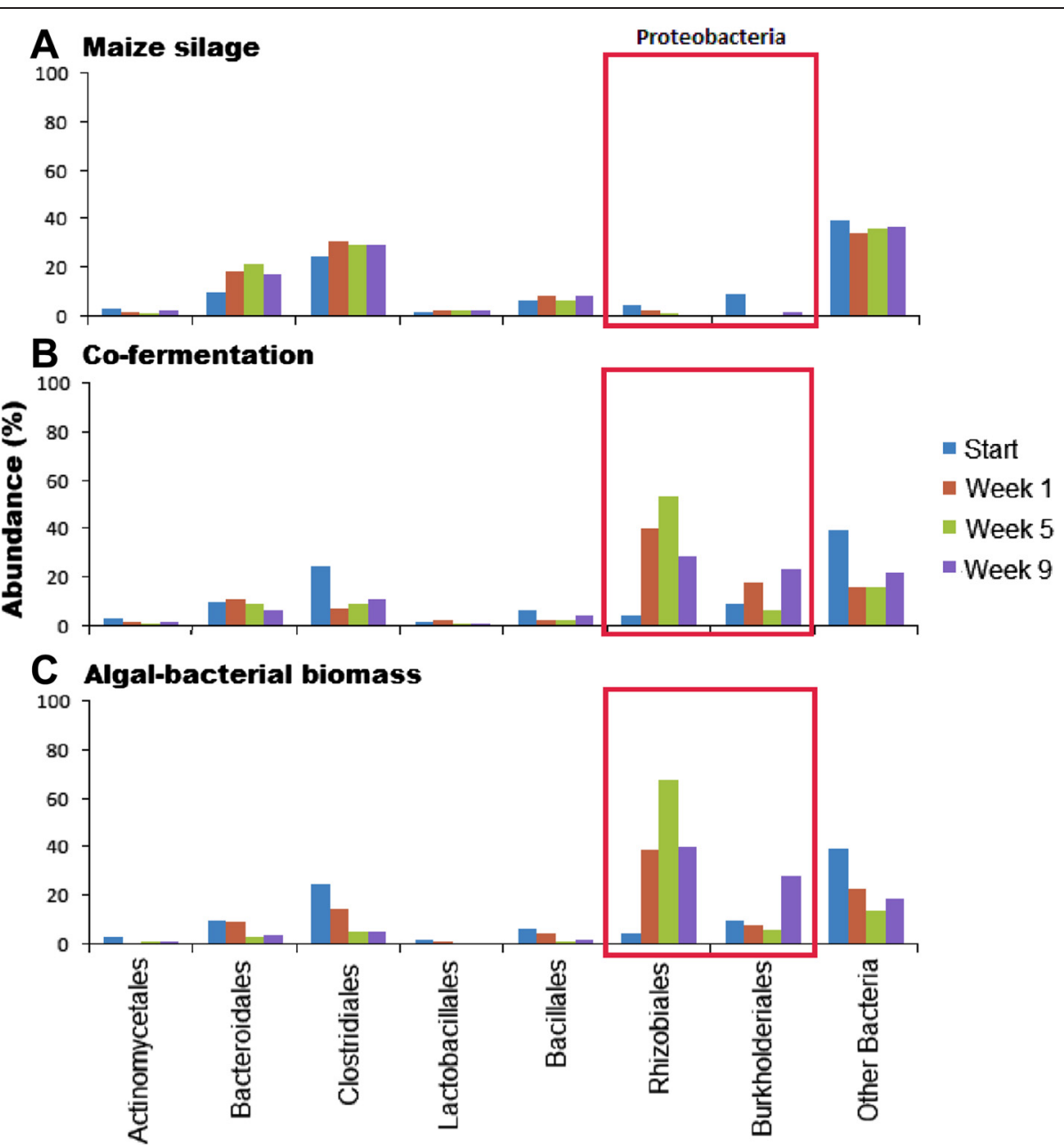

Figure 8 Changes in the domain Bacteria of the microbial community at the order level. (A) Maize silage, (B) co-fermentation, and (C) algal-bacterial biomass.

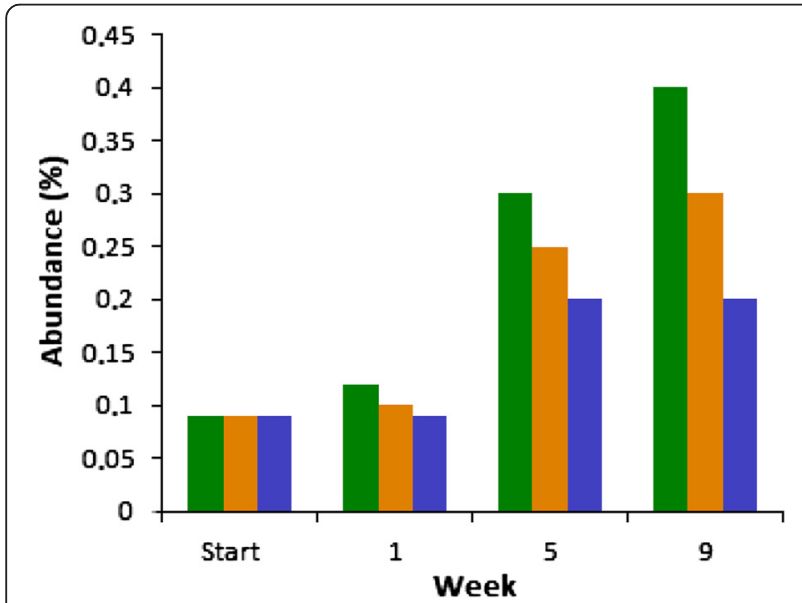

Figure 9 Eukaryotic sequences in the reactors. Green: $A B+S$, orange: co-fermentation, blue: maize silage.

\section{Conclusions}

A combination of bioH $\mathrm{H}_{2}$ and biogas production by a mixture of nonsterile microalgae and natural bacterial flora was demonstrated. In a closed system, the mutualistic bacteria consumed the $\mathrm{O}_{2}$ evolved by the algae and created a sufficiently anaerobic environment for algal $\mathrm{H}_{2}$ evolution without damaging the photosynthetic apparatus of the algae. With the help of the bacterial partners, the algae succeeded in capturing light energy by photosynthetic water splitting and evolved $\mathrm{H}_{2}$ at the same time without the need for further manipulation of the system, such as sulfur deprivation.

$\mathrm{H}_{2}$ production through the use of a mixture of microalgae and syntrophic bacteria started earlier than the $\mathrm{H}_{2}$ evolution following sulfur deprivation, although sulfurdeprived $C$. reinhardtii produced $\mathrm{bioH}_{2}$ for a longer period of time.

$\mathrm{AD}$ and biogas evolution from the nonsterile microalgalbacterial biomass yielded a gas enriched in $\mathrm{CH}_{4}$ relative to 


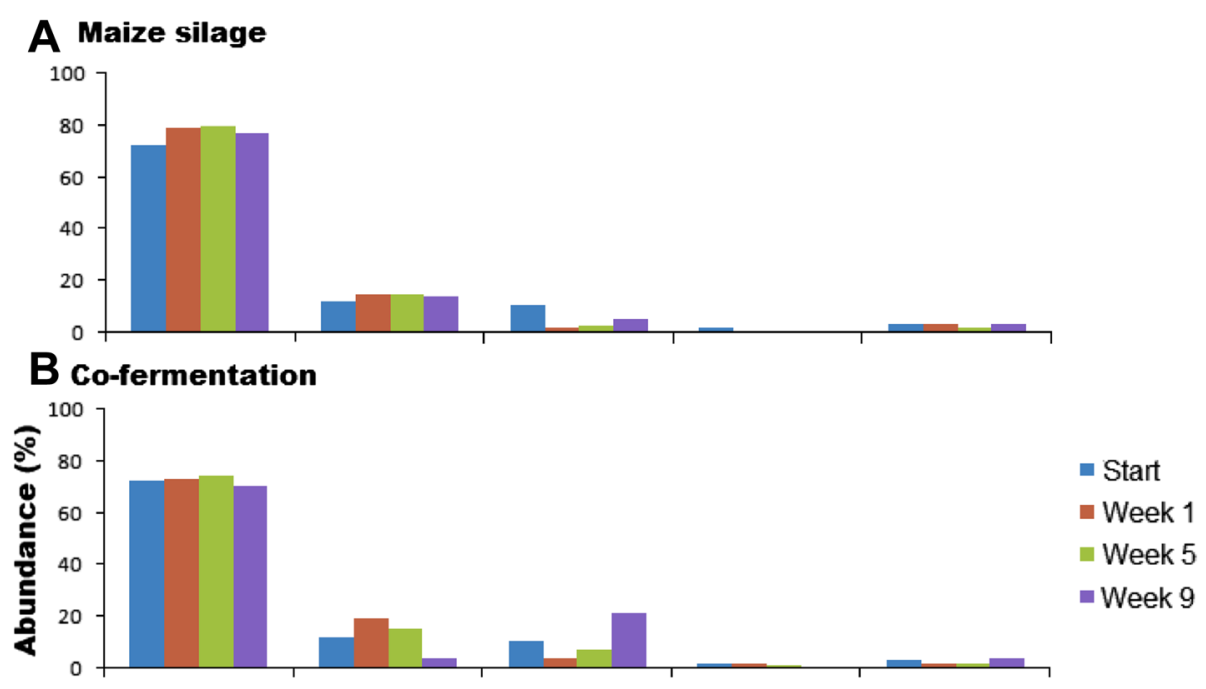

C Algal-bacterial biomass

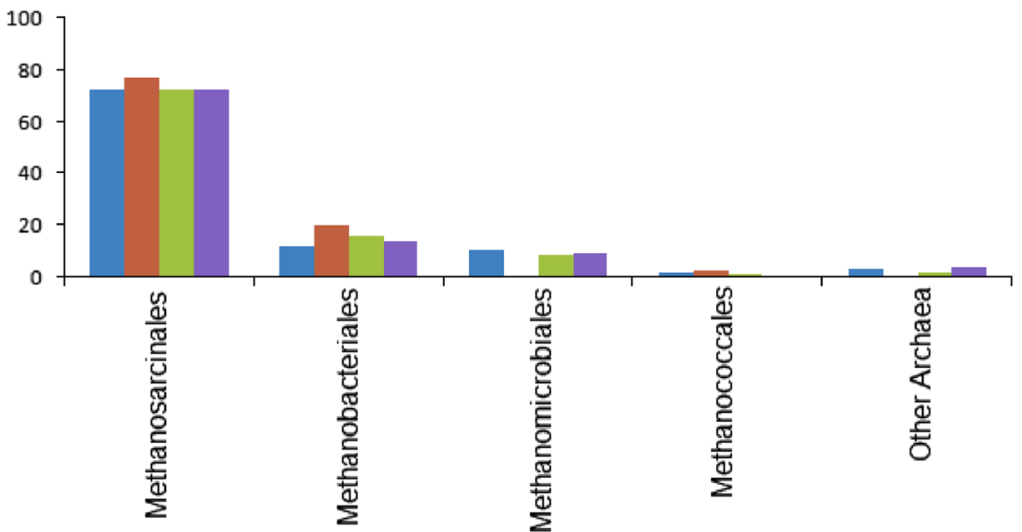

Figure 10 Distribution of the domain Archaea in the microbial community at the order level. (A) Maize silage, (B) co-fermentation, and $(\mathbf{C})$ algal-bacterial biomass.

the commonly used maize silage. The specific biogas production estimated on the basis of the organic material input, however, was smaller than that from maize silage. The addition of maize silage to the algal-bacterial mixed biomass increased the $\mathrm{C} / \mathrm{N}$ ratio considerably and improved the balanced digestibility of the microbial biomass.

The metagenome analysis of the microbial communities present in the $\mathrm{AD}$ reactors revealed the persisting impact of the microalgae and their bacterial companions on the composition of the AD microbial community within a few days. The large amount of bacteria belonging in the genera Rhizobium and Burkholderia, dosed together with the microalgal biomass, significantly changed the bacterial community composition. Co-fermentation of the algalbacterial biomass with maize silage compensated somewhat for the Rhizobium and Burkholderia predominance due to the $50 \%$ lower loading of the microbial biomass on an organic dry matter basis. In the control reactors fed with maize silage, the microbial taxa belonging in the phyla Firmicutes and Bacteroidetes persisted.
Interestingly, the pronounced alterations observed in the domain Bacteria did not affect the composition of the domain Archaea. The order Methanosarcinales predominated in the Archaeal community regardless of the substrate composition.

\section{Materials and methods}

\section{Cultivation of pure and mixed cultures}

The Chlamydomonas sp. and Scenedesmus sp. algae and their mutualistic bacteria $(\mathrm{AB}+\mathrm{S}$ culture) were obtained as algal strain 810 from the Mosonmagyaróvár Algal Culture Collection (MACC) of Hungary. The purified algal mixture was maintained and cultivated on TP (TRIS-phosphate) medium supplemented with rifampicin. The TP medium is a modified TAP (TRIS-Acetate-Phosphate) medium where acetate is replaced with $\mathrm{HCl}$. The TAP and TP plates were incubated under $50 \mu \mathrm{mol} \mathrm{m} \mathrm{m}^{-2}$ light intensity at $25^{\circ} \mathrm{C}$. Algae used for $\mathrm{H}_{2}$-evolution experiments were harvested as fresh cultures grown on TP-agar plates supplemented with rifampicin and transferred into liquid TAP medium 
$[41,71,72]$. The algal stock solutions were equally distributed into 40-mL Hypo-Vial bottles, resulting in a final volume of $35 \mathrm{~mL}$ and a final optical density $\left(\mathrm{OD}_{750}\right)$ of 0.7. E. coli $\triangle h y p F$, a hydrogenase-deficient strain, was grown on $\mathrm{LB}$ (Luria-Bertani medium) plates at $30^{\circ} \mathrm{C}$ in the dark.

The original algal-bacterial culture, used for $\mathrm{H}_{2}$ production experiments, was pre-grown in TAP medium. The medium of the pre-grown stock culture was changed to fresh TAP medium by centrifugation. It was diluted to $\mathrm{OD}_{750}$ of 1.2. Bottles were sealed with butyl rubber stoppers and aluminum caps. All experiments were performed in at least three parallel repetitions.

\section{Algal-bacterial culture scaling up for biomass production} For biomass production, an unpurified culture of a Scenedesmus sp. and Chlamydomonas sp. mixture, as obtained from the MACC collection, was cultivated in 13-L polycarbonate vessels under $50 \mu \mathrm{mol} \mathrm{m}{ }^{-2} \mathrm{~s}^{-1}$ light intensity at $25^{\circ} \mathrm{C}$ for 5 days before harvesting. The biomass yield was approximately $2 \mathrm{~g} \mathrm{~L}^{-1}$. The microbial biomass was harvested by using a cross-flow centrifuge and the harvested biomass was stored at $-20^{\circ} \mathrm{C}$ until utilization.

\section{Gas chromatographic analyses}

The $\mathrm{H}_{2}$ and $\mathrm{O}_{2}$ levels in the headspace of the Hypo-Vial bottles were measured by gas chromatography. An Agilent 7890A gas chromatograph (Agilent Technologies, Santa Clara, USA), equipped with a thermal conductivity detector and an Agilent HP-Molsieve column (length $30 \mathrm{~m}$, diameter $0.320 \mathrm{~mm}$, film $12.0 \mu \mathrm{m}$; Agilent Technologies, Santa Clara, USA) was used in splitless mode. Linde HQ argon 5.0 (Linde Group, Munich, Germany) was used as carrier and reference gas. The temperatures of the injector, TCD detector, and column were kept at $150^{\circ} \mathrm{C}, 160^{\circ} \mathrm{C}$, and $60^{\circ} \mathrm{C}$, respectively. The column pressure was 47.618 psi. The flow rate of the column was $12 \mathrm{~mL} \mathrm{~min}^{-1}$. Samples $(50 \mu \mathrm{L})$ were analyzed. Three biological replicates were used for the measurements. A $\mathrm{H}_{2}$ calibration curve was used to determine accurate gas volumes. Serial dilutions of pure $\mathrm{H}_{2}$ gas were prepared in 25 -mL gas-tight vials, and identical volumes were injected into the gas chromatograph: data from three replicates were used to draw the $\mathrm{H}_{2}$ calibration curve.

\section{Anaerobic fermentation and biogas analysis}

Anaerobic fermentations were carried out in 5-L continuously stirred tank reactors [73], and the fed-batch operational mode was used. The reactors were operated by using a pig manure and maize silage mixture [59] until the biogas production stabilized. This start-up period lasted for 4 to 5 weeks. Feeding with the various substrate compositions was started thereafter. One of the reactors was fed with a $\mathrm{AB}+\mathrm{S}$ loading of $1 \mathrm{~g}$ oDM L $\mathrm{L}^{-1}$ day $^{-1}$, an identical reactor was supplied with $A B+S$ and corn silage $(0.5+0.5$ $\mathrm{g}$ oDM L $\left.{ }^{-1} \mathrm{day}^{-1}\right)$, and the control received only corn silage $\left(1 \mathrm{~g} \mathrm{oDM} \mathrm{L}^{-1} \mathrm{day}^{-1}\right)$. The initial parameters of the substrates are summarized in Table 1 . Heating was maintained by means of an electronically heated jacket which surrounded the cylindrical apparatus. Temperature was measured with a bimetallic sensor and was maintained constant at $37^{\circ} \mathrm{C} \pm 1.0^{\circ} \mathrm{C}$. The $\mathrm{pH}$ was between 7 and 8 , and the redox potential was $<-500 \mathrm{mV}$. The generated gas and its quality were measured daily after the 1-month start-up (weeks 1 to 4 ) and stabilization phase on the designated substrate. Gas volumes were measured with thermal mass flow devices (DMFC; Brooks Instrument, Hatfield, USA) attached to each gas exit port. The composition of the evolved biogas was measured with a gas chromatograph (6890 N Network GC System, Agilent Technologies, Santa Clara, USA) equipped with a $5 \AA$ molecular sieve column (length $30 \mathrm{~m}$, I.D. 0.53 megabore, film $25 \mu \mathrm{m}$ ). Ultrapure $\mathrm{N}_{2}$ was used as carrier gas.

\section{Determination of fermentation parameters $o D M$}

The dry organic matter content was quantified by drying the biomass at $105^{\circ} \mathrm{C}$ overnight and weighing the residue giving the dry mass content. Further heating of this residue at $550^{\circ} \mathrm{C}$ provided the organic dry mass content.

\section{Density measurement}

Sample density was measured with a MINIDENS automatic density meter (Grabner Instruments, Wien, Austria).

\section{$\mathrm{C} / \mathrm{N}$}

To determine $\mathrm{C} / \mathrm{N}$, an Elementar Analyzer Vario MAX CN (Elementar Group, Hanau, Germany) was employed. The equipment works using the principle of catalytic tube combustion under an $\mathrm{O}_{2}$ supply at high temperatures

Table 2 Lysis conditions for total community DNA preparation

\begin{tabular}{|c|c|c|c|c|c|}
\hline & Lysozyme $^{a}(\mu \mathrm{L})$ & $10 \%$ CTAB $^{\mathrm{b}}(\mu \mathrm{L})$ & Genomic CTAB lysis buffer ${ }^{c}(\mu \mathrm{L})$ & Qiagen buffer $^{d}(\mu \mathrm{L})$ & Zymo buffer $^{\mathrm{e}}(\mu \mathrm{L})$ \\
\hline$A$ & - & 100 & - & 100 & 550 \\
\hline B & 250 & 100 & - & 100 & 300 \\
\hline$C$ & 250 & - & 300 & 200 & - \\
\hline
\end{tabular}

${ }^{\mathrm{a}} 100 \mathrm{mg} \mathrm{mL}^{-1}$ (Applichem, Barcelone, Spain). ${ }^{\mathrm{b}}$ Cetyltrimethylammonium bromide (w/v). ${ }^{\mathrm{c}} 1 \mathrm{M}$ Tris-HCl $100 \mathrm{~mL}, 500 \mathrm{mM} \mathrm{EDTA} 50 \mathrm{~mL}, 5 \mathrm{M} \mathrm{NaCl} 300 \mathrm{~mL}, 10 \% \mathrm{CTAB}$, $20 \%$ SDS, pH $=8$ (Wirth et al. [64]). ${ }^{\mathrm{d}}$ ASL buffer from Qiagen QIAamp DNA Stool miniprep kit (51504, Qiagen, Limburg,Netherlands). ${ }^{\mathrm{e}}$ From Zymo Research Fecal DNA kit (Zymo Research, D6010). 
(combustion temperature: $900^{\circ} \mathrm{C}$, postcombustion temperature: $900^{\circ} \mathrm{C}$, reduction temperature: $830^{\circ} \mathrm{C}$, column temperature: $250^{\circ} \mathrm{C}$ ). The desired components were separated from each other with the aid of specific adsorption columns (containing Sicapent (Merck, Billerica, USA), in $\mathrm{C} / \mathrm{N}$ mode) and determined in succession with a thermal conductivity detector. Helium served as flushing and carrier gas.

\section{$\mathrm{NH}_{4}^{+}-\mathrm{N}$}

For the determination of $\mathrm{NH}_{4}^{+}$ion content, the Merck Spectroquant Ammonium test (1.00683.0001) (Merck, Billerica, USA) was used. At the beginning of the experiment the $\mathrm{NH}_{4}^{+}-\mathrm{N}$ was $1,100 \mathrm{mg} \mathrm{L}{ }^{-1}$.

\section{VOAs/TAC}

Five grams of fermenter sample was taken for the analysis and diluted to $20 \mathrm{~g}$ with distilled water. The subsequent process was carried out with Pronova FOS/TAC 2000 Version 812-09.2008 automatic titrator (Pronova, Berlin, Germany). At the beginning of the experiment the VOAs/TAC ratio was 0.2 .

\section{DNA isolation for metagenomic studies}

Two-milliliter samples, taken from the reactors, were used for total community DNA isolation. The extractions were carried out with a slightly modified version of the Zymo Research kit (D6010, Zymo Research, Irvine, USA). Parallel samples from each reactor were lysed with three different lysis mixes (Table 2). After lysation (bead beating), the Zymo Research kit protocol was followed. The quantity of DNA was determined in a NanoDrop ND-1000 spectrophotometer (NanoDrop Technologies, Wilmington, USA) and a Qubit 2.0 Fluorometer (Life Technologies, Carlsbad, USA). DNA purity was tested by agarose gel electrophoresis and with an Agilent 2200 Tape Station (Agilent Technologies, Santa Clara, USA).

\section{Next-generation DNA sequencing and data handling}

The sample preparation for total metagenome sequencing of the pooled samples was carried out following the recommendations of the Ion Torrent PGM sequencing platform (Life Technologies, Carlsbad, USA). Sequencing was performed with Ion Torrent PGM 316 chips. The reads were analyzed and quality values were determined for each nucleotide. The 150 to 250 nucleotide-long individual sequences were further analyzed by using the MG-RAST software package [74], which is a modified version of Rapid Annotations based on Subsystem Technology (RAST). The MG-RAST server computes results against several reference datasets (protein and ribosomal databases) [75]. The generated matches to external databases were used to compute the derived data $[59,76]$.

\begin{abstract}
Abbreviations
A + S: mixture of Chlamydomonas sp., and Scenedesmus sp., non-sulfur deprived; $\mathrm{AB}+\mathrm{S}$ : mixture of Chlamydomonas sp., Scenedesmus sp., and mutualistic bacteria, non-sulfur deprived; AD: Anaerobic digestion; AE + S: mixture of Chlamydomonas sp., Scenedesmus sp., and Escherichia coli $\triangle$ hypF, non-sulfur deprived; A-S: mixture of Chlamydomonas sp., and Scenedesmus sp., sulfur deprived; oDM: organic dry matter; TAC: Total alkaline capacity; TAP: TRIS-acetate-phosphate medium;

TP: TRIS-phosphate medium; VOS: Volatile organic acids.
\end{abstract}

\section{Competing interests}

The authors declare that they have no competing interests.

\section{Authors' contributions}

RW and ZB developed the DNA extraction protocol, designed and performed the experiments, and contributed to the evaluation of metagenomic data. GL helped in the cultivation of the algal-bacterial biomass. GM organized and performed the DNA sequencing work. KLK and ZB conceived the project and participated in its design. RW and KLK drafted the manuscript. GR critically evaluated the manuscript. ÉK analyzed and revised the manuscript. JM and KN analyzed the data and participated in the writing of the manuscript. All authors read and approved the final manuscript.

\section{Authors' information}

RW is a postdoctoral fellow at the Department of Biotechnology, University of Szeged, Szeged, Hungary. GL is a PhD student at the Department of Biotechnology, University of Szeged and Institute of Biochemistry, Hungarian Academy of Sciences, Szeged, Hungary. GM is Head of the Metagenomics Laboratory, Institute of Biochemistry, Biological Researh Center, Hungarian Academy of Sciences, Szeged, Hungary. ZB is an Assistant Professor at the Department of Biotechnology, while JM and KN are Full Professors at the Department of Oral Biology and Experimental Dentistry, University of Szeged. ÉK is Full Member of the Hungarian Academy of Sciences and a Senior Scientific Advisor at the Biological Research Center, Hungarian Academy of Sciences. RG is an Associate Professor, Department Chairman, and Director of the Environmental Research Institute at the University of Szeged. KLK is a Full Professor both at the Department of Biotechnology and at the Department of Oral Biology and Experimental Dentistry, University of Szeged; he is a Senior Scientific Adviser at the Institute of Biophysics, Biological Research Center, Hungarian Academy of Sciences. KLK serves as President of the Hungarian Biogas Association.

\section{Acknowledgements}

The authors thank Ms. Netta Bozóki for technical assistance. This work was supported by the domestic grants GOP-1.1.1-11-2012-0128, TÁMOP-4.2.2.A-11/1/ KONV-2012-0007 and PIAC_13-1-2013-0145 and by the EU projects H2020-LCE-2014-3 646533 BIOSURF and 'SYMBIOTICS' ERC AdG to Éva Kondorosi.

\section{Author details}

'Department of Biotechnology, University of Szeged, Közép fasor 52, H-6726 Szeged, Hungary. ${ }^{2}$ Institute of Biochemistry, Biological Research Center, Hungarian Academy of Sciences, Temesvári krt. 62, H-6726 Szeged, Hungary. ${ }^{3}$ Institute of Biophysics, Biological Research Center, Hungarian Academy of Sciences, Temesvári krt. 62, H-6726 Szeged, Hungary. ${ }^{4}$ Department of Oral Biology and Experimental Dental Research, University of Szeged, Tisza L. krt. 64, 6720 Szeged, Hungary.

Received: 30 October 2014 Accepted: 20 March 2015

Published online: 08 April 2015

\section{References}

1. McKendry P. Energy production from biomass (Part2-3): conversion technologies. Biores Technol. 2002;83:47-63.

2. Angelidaki I, Ellegaard L. Codigestion of manure and organic wastes in centralized biogas plants: status and future trends. Appl Biochem Biotechnol. 2003;109:95-105.

3. Santosh Y, Sreekrishnan TR, Kohli S, Rana V. Enhancement of biogas production from solid substrates using different techniques-a review. Biores Technol. 2004; $95: 1-10$

4. Goyal HB, Seal D, Saxena RC. Bio-fuels from thermochemical conversion of renewable resources: a review. Renew Sust Energy Rev. 2008;12:504-17. 
5. Schenk PM, Thomas-Hall SR, Stephens E, Marx UC, Mussgnug JH, Posten C, et al. Second generation biofuels: high efficiency microalgae for biodiesel production. Bioenergy Res. 2008;1:20-43.

6. Johanson D, Azar CA. Scenario based analysis of land competition between food and bioenergy production in the US. Climate Change. 2007;82:267-91.

7. Richmond A. Handbook of Microalgal culture: Biotechnology and Applied Phycology. Oxford: Blackwell Science; 2004.

8. Rodolfi L, Zitteli GC, Bassi N, Padovani G, Biondi N, Bonini G, et al. Microalgae for oil: strain selection, induction of lipid synthesis and outdoor mass cultivation in a low-cost photobioreactor. Biotechnol Bioeng. 2009;102:100-12

9. Edward M. The algal industry survey - a white paper by Dr. Mark Edward. In: Association with the Centre for Management Technology. 2009.

10. Singh J, Gu S. Commercialization potential of microalgae for biofuels production. Renew Sust Energy Rev. 2010;14:2596-610.

11. Guccione A, Biondi A, Sampietro G, Rodolfi L, Bassi N, Tredici MR. Chlorella for protein and biofuels: from strain selection to outdoor cultivation in green wall panel photobioreactor. Biotechnol Biofuels. 2014;7:84. doi:10.1186/1754-6834-7-84.

12. Posten C, Schaub G. Microalgae and terrestrial biomass as a source for fuels - a process view. J Biotechnol. 2009;142:64-9.

13. Harun $R$, Singh M, Forde MG, Danquah KM. Bioprocess engineering of microalgae to produce a variety of consumer products. Renew Sust Energy Rev. 2010;14:1037-47.

14. Chen P, Min M, Chen Y, Wang L, Li Y, Chen Q, et al. Review of biological and engineering aspects of algae to fuels approach. Int J Agric Biol Eng. 2009:2:1.

15. González-Delgado AD, Kafarov V. Microalgae based biorefinery: issues to consider. A review. CT\&F - Ciencia Tecnología y Futuro. 2011;4:5-22.

16. Yen H-W, Hu I-C, Chen C-Y, Ho S-H, Lee D-J, Chang J-S. Microalgae based biorefinery - from biofuels to natural products. Biores Technol. 2013;135:166-74.

17. Becker EW. Microalgae: Biotechnology and Microbiology. Cambridge, UK: Cambridge University Press; 1994.

18. Golueke CG, Oswald WJ, Gotaas HB. Anaerobic digestion of algae. Appl Microbiol. 1957:5:47-55.

19. Uziel M, Oswald WJ, Golueke CG. Solar energy fixation and conversion with algal-bacterial system. Washington, D.C: U.S. National Science Foundation Rep. No. NSF-RA-N-74-195, NSF; 1974.

20. Keenan JD. Bioconversion of solar energy to methane. Energy. 1977;2:365.

21. Binot R, Martin D, Nyns EJ, Naveau H. Digestion anaerobic d'algues cultivees dans les eaux de refroidissement industrielles. Martigues, France: Proc. Heliosynthese aquaculture Semin; 1977.

22. Samson R, Le Duy A. Biogas production from anaerobic digestion of Spirulina maxima algal biomass. Biotechnol Bioeng. 1982;24:1919.

23. Becker EW. The production of microalgae a source of biomass. Biomass Util. 1983;67:205

24. Hernández EPS, Córdoba LT. Anaerobic digestion of Chlorella vulgaris for energy production. Res Con Recyc. 1993;9:127-32.

25. Mussgnug $\mathrm{JH}$, Klassen V, Schlüter A, Kruse O. Microalgae as a substrates for fermentative biogas production in a combined biorefinery concept. J Biotechnol. 2010;150:51-6.

26. De Schamphelaire L, Verstraete $W$. Revival of the biological sunlight to biogas energy conversion system. Biotechnol Bioeng. 2009;103:296-304.

27. JT, Tramp C, Sims RC, Miller CD. Characterization of a methanogenic community within an algal fed anaerobic digester. ISRN Microbiol. 2012. doi:10.5402/2012/753892.

28. Melis A, Happe T. Hydrogen production. green algae as a source of energy Plant Physiol. 2001;127:740-8.

29. Zhang L, Happe T, Melis A. Biochemical and morphological characterization of sulfure-deprived and $\mathrm{H}_{2}$ - producing Chlamydomonas reinhardtii (green alga). Planta. 2002;21:552-61.

30. Fouchard S, Hemscheimer A, Caruana A, Pruvost J, Legrand J, Happe T, et al. Autotrophic and mixotrophic hydrogen photoproduction in sulfur-deprived Chlamydomonas reinhardtii cells. Appl Environ Microbiol. 2005;10:6199-205.

31. Keshtacher-Liebso E, Hadar Y, Chen Y. Oligotrophic bacteria enhance algal growth under iron - deficient conditions. Amer Soc Microbiol. 1995;61:2411-39.

32. Watanabe K, Takihana N, Aoyagi H, Hanada S, Watanabe Y, Ohmura N, et al. Symbiotic association in Chlorella culture. FEMS Microbiol Ecol. 2005;51:187-96.
33. Nikolaev YA, Plakunov YK, Voronina NA, Nemtseva NV, Platnikov AO, Gogoleva OA, et al. Effect of bacterial satellites on Chlamydomonas reinhardtii in an algo-bacterial community. Microbiology. 2008;77:78-83.

34. Amin SA, Green DH, Hort MC, Küpper FC, Sunda WG, Carrano JC. Photolysis of ion - siderophore chelates promotes bacteria - algal mutualism. Proc Natl Acad Sci U S A. 2009;106:17071-6.

35. Rivas MO, Vargas P, Riquelme CE. Interactions of Botryococcus braunii cultures with bacterial biofilms. Microb Ecol. 2010;60:628-35.

36. Kazamia E, Czesnick H, Nguyen TTV, Croft MT, Sherwood E, Sasso S, et al. Mutualistic interaction between vitamin B-12 dependent algae and heterotrophic bacteria exhibit regulation. Environ Microbiol. 2012;14:1466-76.

37. Xie B, Bishop S, Stessman D, Wright D, Spalding MH, Halverson LJ. Chlamydomonas reinhardtii thermal tolerance enhancement mediated by mutualistic interaction with vitamin $B_{12}$-producing bacteria. ISME J. 2013;7:1544-55.

38. Chwenk D, Nohynek L, Rischer H. Algae bacteria association inferred by 165 rDNA similarity in established microalgae cultures. Microbiol. 2014;3:356-68.

39. Kim B-H, Ramanan R, Cho D-H, Oh H-M, Kim H-S. Role of Rhizobium, a plant growth promoting bacterium, in enhancing algal biomass through mutualistic interaction. Biomas Bioenergy. 2014;69:95-105.

40. Wu S, Li X, Yu J, Wang Q. Increased hydrogen production in co-culture of Chlamydomonas reinhardtii and Bradyrhizobium japonicum. Biores Technol. 2012;123:184-8.

41. Lakatos G, Deák ZS, Vass I, Rétfalvi T, Rozgonyi Sz, Rákhely G, et al. Bacterial synbionts enhance photo-fermentative hydrogen evolution of Chlamydomonas algae. Green Chem. 2014. doi:10.1039/C4GC00745J.

42. Maier T, Binder U, Böck A. Analysis of the hydA locus of Escherichia coli: two genes (hydN and hypF) involved in formate and hydrogen metabolism. Arch Microbiol. 1996;165:333-41.

43. Melis A, Zhang L, Seibert M. Sustained photobiological hydrogen gas production upon reversible inactivation of oxygen evolution in the green alga Chlamydomonas reinhardtii. Plant Physiol. 2000;122:127-36.

44. Ghirardi ML, Zhang L, Lee JW, Flynn T, Seibert M, Greenbaum E, et al. Microalgae: a green source of renewable $\mathrm{H}_{2}$. Trends Biotechnol. 2000;18:506-11.

45. Kosourov SN, Batyrova KA, Petushkova EP, Tsygankov AA, Ghirardi ML, Seibert M. Maximizing the hydrogen photoproduction yields in Chlamydomonas reinhardtii cultures: the effect of the $\mathrm{H}_{2}$ partial pressure. Int J Hydrogen Energy. 2012;37:8850-8.

46. Ward AJ, Lewis DM, Green FB. Anaerobic digestion of algae biomass: a review. Algal Res. 2014. doi:10.1016/j.algal.2014.02.001.

47. Amon T, Gruber W, Hoffstede U, Jäger $P$, Jäkel K, Kaiser F, et al. Gasausbeute in landwirtschaftichen biogasanlagen. KTBL; 2010. ISBN:978-3-941583-49-9. BOKU University, Wien, Austria 2010

48. McGhee TJ. A method for approximation of the volatile acid concentrations in anaerobic digesters. Water Sewage Works. 1968;115:162-6.

49. Nordmann W. Die Überwachtung der Schlammfaulunk. KA-Informationen für das Betriebspersonal, Beilage zur Korrespondenz Abwasser. 1977. 3/77.

50. Alexander M. Biodegradation of organic chemicals. Environ Sci Technol. 1985;19:106-11.

51. Chen Y, Cheng JJ, Creamer KS. Inhibition of anaerobic digestion process: a review. Biores Technol. 2008;99:4044-64.

52. Nielsen HB, Angelidaki I. Strategies for optimizing recovery of the biogas process following ammonia inhibition. Biores Technol. 2008;99:7800-995.

53. Parkin GF, Owen WF. Fundamental of anaerobic-digestion of wastewater sludge. J Environ Eng. 1986;112:867-920.

54. Yadvika S, Sreekrishnan TR, Kohli S, Rana V. Enhancement of biogas production from solid substrates using different techniques - a review. Biores Technol. 2004:95:1-10.

55. Olsson J, Shadiimam MA, Nehrenheim E, Thorin E. Co-digestion of cultivated microalgae and sewage from municipal waste water treatment. International Conference on Applied Energy ICAE 2013 Jul. 1-4. 2013, Pretoria, South Africa, Paper ID: ICAE2013-518.

56. Yen H-W, Brune DE. Anaerobic co-digestion of algal sludge and waste paper to produce methane. Biores Technol. 2007;98:130-4.

57. Makarova K, Slesarev A, Wolf Y, Sarokin A, Mirkin B, Koonin E, et al. Comparative genomics of the lactic acid bacteria. Proc Natl Acid Sci USA. 2006;103:15611-6.

58. Yamada Y, Yukphan P. Genera and species in acetic acid bacteria. Int J Food Microbiol. 2008;125:15-24. 
59. Wirth R, Kovács E, Maroti G, Bagi Z, Rakhely G, Kovacs KL. Characterization of a biogas-producing microbial community by short-read next generation DNA sequencing. Biotechnol Biofuels. 2012;5:1-16.

60. Daniel RM, Smith M, Phillip AD, Ratcliffe HD, Drozd JW, Buel AT. Anaerobic growth and denitrification by Rhizobium japonicum and other Rihzobia. J Gen Microbiol. 1980:120:517-21.

61. Tjepkema J, Evans HJ. Nitrogen fixation by free-living Rhizobium in a defined liquid medium. Biochem Biophys Res Commun. 1975;65:625-8.

62. Schlüter A, Bekel T, Diaz NN, Dondrup M, Eichenlaub R, Gartemann KH, et al. The metagenome of a biogas-producing microbial community of a production-scale biogas plant fermenter analyzed by the 454-pyrosequencing technology. J Biotech. 2008;136:77-90.

63. Krause L, Diaz NN, Edwards RA, Gartemann K-H, Krömeke H, Neuwger H, et al. Taxonomic composition and gene content of a methane-producing microbial community isolated from a biogas reactor. J Biotech. 2008;136:91-101.

64. Kröber M, Bekel T, Diaz NN, Goesmann A, Sebastian J. Phylogenetic characterization of a biogas plant microbial community integrating clone library 165 -rDNA sequences and metagenome sequence data obtained by 454-pyrosequencing. J Biotech. 2009;142:38-49.

65. Stantscheff R, Kuever J, Rabenstein A, Seyfarth K, Dröge S, König H. Isolation and differentiation of methanogenic Archaea from mesophilic corn-fed on-farm biogas plants with special emphasis on the genus Methanobacterium. Appl Environ Biotechnol. 2014;98:5719-35.

66. Ziganshina EE, Bagmanova AR, Khilyas IV, Ziganshin AM. Assessment of biogas-generating microbial community in a pilot-scale anaerobic reactor. J Biosci Bioeng. 2014:117:730-6.

67. Sirohi SK, Pandey N, Singh B, Puniya AK. Rumen methanogens: a review. Indian J Microbiol. 2010;50:253-62.

68. Rastogi G, Ranade DR, Yeole TY, Patole MS, Houche YS. Investigation of methanogen population structure in biogas reactor by molecular characterization of methyl-coenzyme $\mathrm{M}$ reductase $\mathrm{A}(\mathrm{mcr})$ genes. Biores Technol. 2008;99:5317-26.

69. Lee C, Kim J, Hwang K, O'Flaherty V, Hwang S. Quantitative analysis of methanogenic community dynamics in three anaerobic batch digesters treating different wastewaters. Water Res. 2009:43:157-65.

70. Blume F, Bergmann I, Nettmann E, Schelle H, Rehde G, Munkdt K, et al. Methagenomic population dynamics during semi-continuous biogas fermentation and acidification by overloading. J Appl Microbiol. 2010;109:441-50.

71. Sialve B, Bernet N, Bernard O. Anaerobic digestion of microalgae as a necessary step to make microalgal biodiesel sustainable. Biotechnol Adv. 2009. doi:10.1016/j.biotechadv.2009.03.001

72. Lakaniemi A-M, Hulatt CJ, Thomas DN, Tuovinen OH, Puhakka JA. Biogenic hydrogen and methane production from Chlorella vulgaris and Dunaliella tertiolecta biomass. Biotechnol Biofuels. 2011:4:34

73. Kovács KL, Ács N, Kovács E, Wirth R, Rákhely G, Strang O, et al. Improvement of biogas production by bioaugmentation. BioMed Res Internat. 2013. http://dx.doi.org./10.1155/2013/482653.

74. Meyer F, Paarmann D, D'Souza M, Olson R, Glass EM, Kubal M, et al. The metagenomics RAST server - a public resource for the automatic phylogenetic and functional analysis of metagenomes. BMC Bioinformatics. 2008;9:386.

75. MG-RAST manual for version 3.3.6 revision 9. ftp://ftp.metagenomics.anl.gov/ data/manual/mg-rast-manual.pdf.

76. Kovács E, Wirth R, Maróti G, Bagi Z, Rákhely G, Kovács KL. Biogas production from protein-rich biomass: fed-batch anaerobic fermentation of casein and pig blood and associated changes in microbial community composition. PLoS One. 2013;8(10), e77265.

\section{Submit your next manuscript to BioMed Central and take full advantage of:}

- Convenient online submission

- Thorough peer review

- No space constraints or color figure charges

- Immediate publication on acceptance

- Inclusion in PubMed, CAS, Scopus and Google Scholar

- Research which is freely available for redistribution 